Our Nature
Journal homepage: http://nepjol.info/index.php/ON

\title{
Perceptions of climate change and variability, impacts and adaptation strategies by rice farmers in south east Nigeria
}

\author{
Happiness Ogba Oselebe ${ }^{1}$, Catherine Veronica Nnamani ${ }^{2}$, Andrew Efisue ${ }^{3}$, Donatus \\ Onu $^{4}$, Simeon Okpoto Eze ${ }^{4}$, Johnny O. Ogunji ${ }^{* *}$ \\ ${ }^{1}$ Department of Crop Production and Landscape Management, Ebonyi State University, Abakaliki, Nigeria \\ ${ }^{2}$ Plant Taxonomy/Biosystematics and Biodiversity Conservation Unit, Department of Applied Biology, Ebonyi \\ State University, Abakaliki, Nigeria \\ ${ }^{3}$ Biotechnology Research and Development Centre, Ebonyi State University, Abakaliki, Nigeria \\ ${ }^{4}$ Department of Agricultural Economics and Management, Ebonyi State University, Abakaliki, Nigeria \\ ${ }^{5}$ Department of Fisheries and Aquaculture, Ebonyi State University, Abakaliki, Nigeria \\ *E-mail:ogunjijo@yahoo.com
}

\begin{abstract}
This study was designed to identify level of awareness/knowledge of rice farmers in South-eastern Nigeria about climate-change; identify adverse effects of climatevariability and change on rice production and determine adaptation strategies used by small holder rice farmers within study area. Multistage purposive and stratified sampling technique was used for the sample selection. Information from 360 respondents was got using Rapid Rural Appraisal (RRA), Focus Group Discussions (FGD), and actual survey with questionnaires. Results showed that the rice farmers were aware of weather changes with grave effects on their rice farms. They reported changes in rainfall regime, intense sunshine, high temperature etc. Of special interest among the adaptation strategies by farmers are the use of inorganic fertilizers, improved rice varieties, cultivation of early maturing varieties, and proper preservation of rice seeds. This study recommends urgent measures to improve resilience of smallholder farmers in rural communities to enable them better adapt to climate-change.
\end{abstract}

Key words: Improve rice varieties, Inorganic fertilizers, Rice production, Weather changes

DOI: http://dx.doi.org/10.3126/on.v14i1.16441

Manuscript details: Received: 12.02.2016 / Accepted: 10.09.2016

Citation: Oselebe, H.O., C.V. Nnamani, A. Efisue, D. onu, S.O. Eze and J.O. Ogunji 2016. Perceptions of climate change and variability, impacts and adaptation strategies by rice farmers in south east Nigeri. Our Nature 14(1):54-63. DOI: http://dx.doi.org/10.3126/on.v14i1.16441

Copyright: $\odot$ Oselebe et al. 2016. Creative Commons Attribution-NonCommercial 4.0 International License. 


\section{Introduction}

Over the past century, global average surface temperature has increased approximately by $0.6^{\circ} \mathrm{C}$ and this has actually affected both plants and animals differently. The IPCC's Fourth Assessment (AR4) made clear that Africa is a vulnerability hotspot for climate change. (IPCC, 2001) and is projected that crop yield in Africa may fall by $10-20 \%$ by 2050 or even up to $50 \%$ due to climate change (Jones and Thornton, 2003), particularly because African agriculture is predominantly rain-fed and hence fundamentally dependent on the vagaries of weather. As the people of Africa strive to overcome poverty and advance economic growth, this phenomenon threatens to deepen vulnerabilities, erode hard-won gains and seriously undermine prospects for development (Zoellick, 2009). In Nigeria, climate change affects its economies because its economic activities are natural resource sensitive such as agricultural activities leading to significant reductions in agricultural productivity (Akinbobola et al., 2015).

Rice is one of the food security crops in the continent of Africa, especially Nigeria, but its production is not growing fast enough in relation to the available potentials in the country. Nigeria demand about 5.0 million metric tonnes of rice annually, but about 3.2 million metric tonnes are produced locally running a deficit of about 1.8 million tonnes (ATA, 2012). Decreases in crop production that may be traceable to climate change have been generally observed.

Rice (Oryza sativa L.) production is greatly dependent on environmental factors provided by nature and the optimum combination of these factors, plus production inputs determines yield. Rainfall character- istics (intensity and duration), relative humidity and temperature constitute some environmental factors that affect rice yield and its variability. Climate change through extreme temperatures, frequent flooding, drought and increased salinity of water supply used for irrigation in rice fields also constitute factors that affect agricultural productivity (Manneh et al., 2007). Drastic changes in rainfall patterns and rise in temperatures introduces unfavourable growing conditions into the cropping calendars thereby modifying growing seasons which could subsequently reduce crop productivity.

In Sub-Saharan Africa, according to Komba and Muchapondwa (2015) climate change is set to hit the agricultural sector the most severely and cause suffering, particularly for smallholder farmers. To cushion themselves against potential welfare losses, smallholder farmers need to recognize the changes already taking place in their climate and undertake appropriate investments in adaptation. Several studies conducted to examine perceptions of farmers on climate change have shown that farmers had different perceptions on climate change.

In a study of farmers in Southeast Nigeria, majority of the farmers did not agree that farming contributes to climate change, but were aware of climate change and its effects on agriculture (Enete et al., 2011). On the other hand Uzor et al. (2015) reported that $40.6 \%$ of their respondents in Imo state Nigeria know a little about Climate change while a significant proportion of $21.7 \%$ are clueless. Adebayo et al. (2012) assessed the awareness, vulnerability and adaptation of farmers to climate change in Adamawa state Nigeria. Majority of the farmers in the state are 
aware of climate change and submitted that climate change has affected their farming activities in recent years. They identified climate change effects to included reduced crop yield, shortage of water and biomass for animals due to low rainfall and frequent dry spells. Similarly high temperature causes wilting of crops and diseases while excessive rainfall leads to destruction of farmlands and properties by flooding.

Okonya et al. (2013) posit that there is limited knowledge on whether farmers perceive climate change and how they are responding to the effects of a changing climate. Most studies assessing the potential effects of climate change on African agriculture are regional or national and yet adaptation is place-based and needs the use of place-specific strategies (Deressa et al., 2011). It is therefore important to note that local perceptions cannot be estimated by models and the need to document how the lives of the local people are affected by the recent changes in climate (Okonya et al., 2013) hence this work.

The study was designed to: a) examine rice farmers' perception and knowledge of climate-change in south-eastern Nigeria; b) identify adverse effects of climatechange on rice production and c) determine adaptation strategies used by smallholder rice farmers within study area.

\section{Methodology \\ Study area}

The study area comprised of two states, Ebonyi and Enugu States in south eastern Nigeria (Figs. 1-3). South eastern Nigeria is located within longitudes $5^{\circ} 30^{\prime}$ and $9^{\circ} 30^{\prime} \mathrm{E}$ and latitudes $4^{\circ} 30^{\prime}$ and $7^{\circ} 00^{\prime} \mathrm{N}$, occupying a land area of about $75,488 \mathrm{~km}^{2}$. The population pressure is the most important problem of rural development in this region, recognisable from a broad spectrum of livelihood activities such as intensive agriculture, engagement in non-farm activities and migration into urban cities. All the people who are engaged in both intensive agriculture and non-farm occupation for their livelihood activities constitute the population for the study.

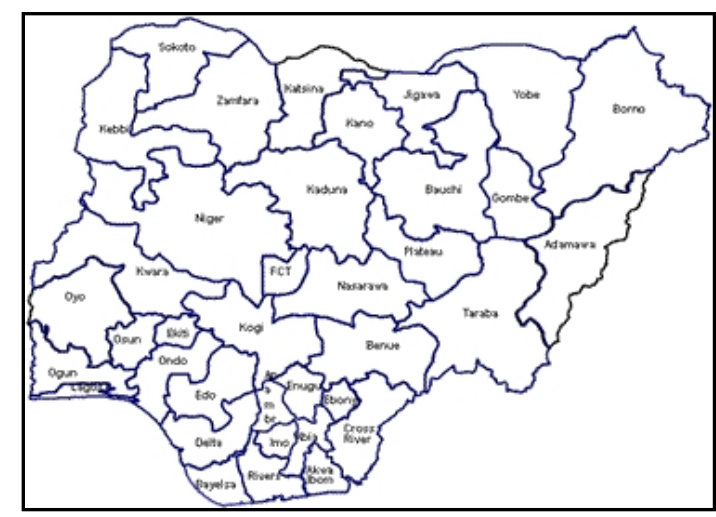

Figure 1. Map of Nigeria showing the states under Study

\section{Data collection}

A representative sample of 360 farmers ( $75 \%$ male and $25 \%$ Female) randomly selected constituted the respondents for the study. Multistage purposive and stratified sampling technique was used for the sample selection based on a sampling frame of contact farmers of the Agricultural Development Programme (ADPs) of study States.

Rapid Rural Appraisal (RRA) and Focus Group Discussions (FGD) were used to establish farmers/stakeholders' awareness and knowledge of climate change, its effects on rice production, including adaptation and resilience strategies. Actual survey was done using questionnaires structured in line with the specific objectives of the study. The instrument was tested for reliability and also validated. Then one-day 
training was conducted for the Field Assistants (16) and Research Assistants (8) to familiarize them with the instruments for data collection prior to actual survey.

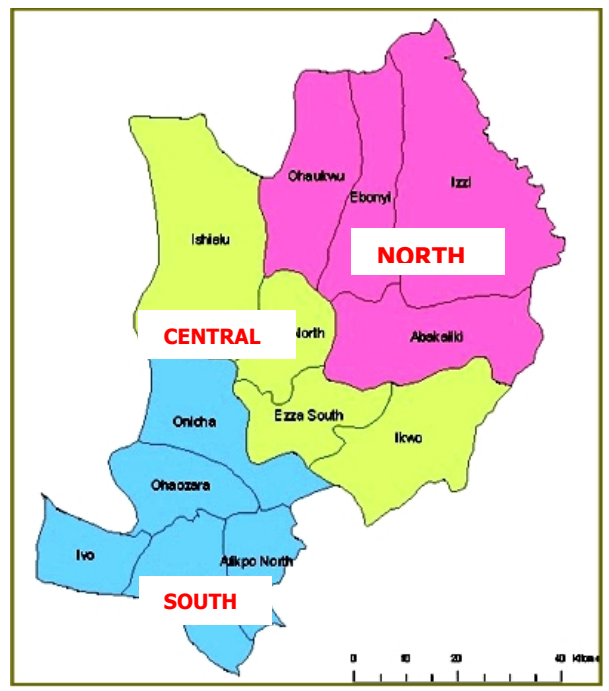

Figure 2. Map of Ebonyi State Nigeria

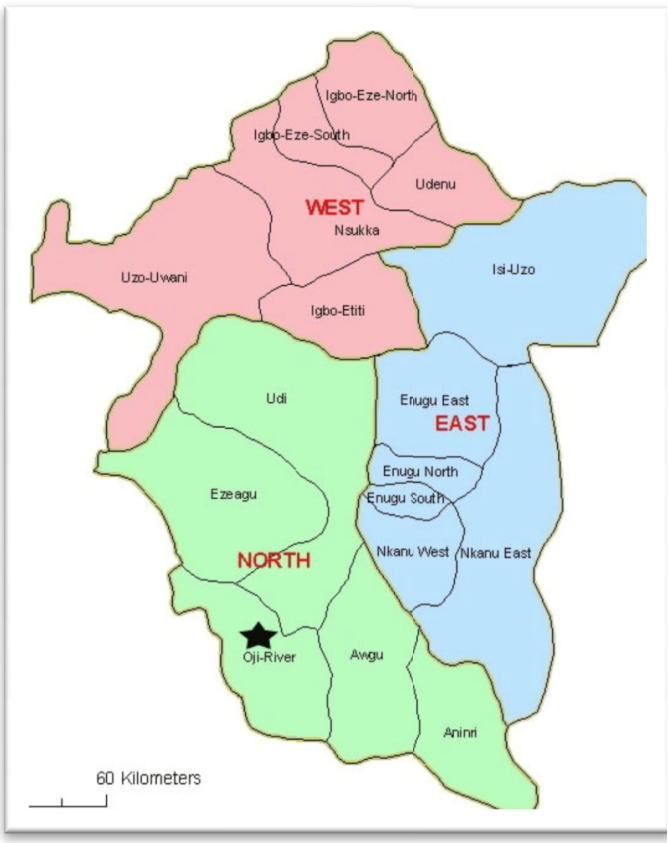

Figure 3. Map of Enugu State Nigeria
The data were analysed with descriptive statistics, percentage distribution and bar charts (Adebayo et al., 2012; Okonya et al., 2013; Uzor et al., 2015)

\section{Results and discussion Farmer awareness of climate change and variability}

All the rice farmers $(100 \%)$ in this study were aware of changes in weather (climate change) in relation to the effects it may be having on their rice farms. They reported specific knowledge of climate change in terms of changes in rainfall regime, intense sunshine, high temperature and flooding (Fig. 4). Most of the farmers (84.4\%) experienced major variations in seasonal changes, while large numbers of them (73.4\%) reported massive floods in their communities. Majority (98.2\%) indicated excessive temperature increase. About eighty six percent $(86.2 \%)$ of the rice farmers experienced variation in life cycle of rice plants. Others experienced reduction in yield of rice due to over flooding $(70.7 \%)$ and excessive temperature $(92.5 \%)$, increase in pest and diseases infestation $(92.8 \%)$ and a sudden and increased loss of rice farm land $(71.6 \%)$. This increased their awareness of impeding food insecurity and hunger (95.2\%).

Uzor et al. (2015) observed that $40.6 \%$ of rural farmers in Imo State Nigeria knew a little about climate change, 31.1 and $6.6 \%$ knew and knew a lot about climate change respectively. Unfortunately a significant proportion of the farmers (21.7\%) does not know anything about climate change. On the other hand Oluwatusin (2014) observed that that most sampled cocoa farmers in Ondo State Nigeria noticed climate change in their area. About $75 \%$ perceived increase in temperature 
around their area for over the last 5 years. Also $81.25 \%$ of them noticed change in climatic condition as increase in rainfall while 150 farmers constituting about 93.75 $\%$ perceived change in the timing of the rain. Only a $3.12 \%$ of them did not detect any change in the condition of climate in the study area.

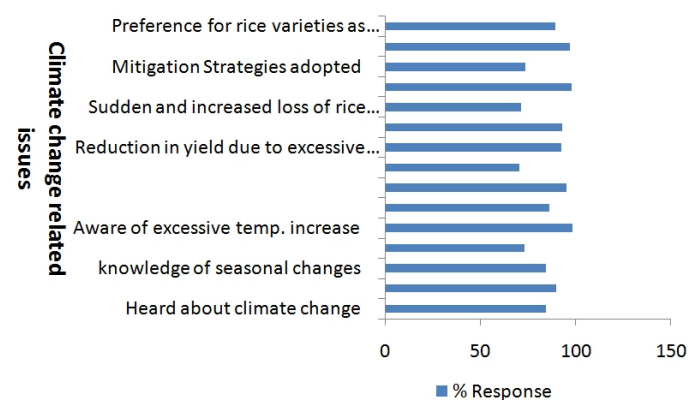

Figure 4. Percentage perception/awareness of smallholder rice farmers in South-eastern Nigeria about climate change related issues.

Reporting a farm level study in Bangladesh, Uddin et al. (2014) showed that some $88 \%$ of respondents indicated that, within the last 20 years, they have, experienced climatic change. The farmers all agreed that they had experienced increases in temperature, droughts, flooding, cyclones, and soil salinity. Across all events, at least $80 \%$ or more reported having experienced climatic shifts which are likely to have a negative impact on agricultural activity. Local people's perception of climate change, its impact and adaptation practices in Norway, revealed that, more than 80 percent have perceived increased temperature and expressed low amount snowfall in High mountain and rainfall in Mid mountain and Tarai region over the last five years. Low amount of snow fall in the Himalayan region affected the Nomad groups due to low grass available to feed their livestock.
Oluwatusin (2014) observed that perception of climate change is directly proportional to the age of the farmers and that older respondents are more efficient in perceiving climate change than the younger respondents. Educational level of farmers also plays a good role in perceiving change in climatic conditions. Benedicta et al. (2010) confirms that the level of education, Among other factors like gender, age, soil fertility, farm size, farming experience, land tenure, access to extension services and credit, all influence farmers perception and adaptation in Ghana.

It is important to note that climate change refers to any change in climate over time whether due to natural variability or as a result of human activity (IPCC, 2007). It could also be defined as any significant change in measures of climate lasting for an extended period. This include changes in average global temperature as well as changes in how frequently regions experience heat, droughts storms floods and other extreme events (CCIR, 2005). The Intergovernmental Panel on Climate Change (IPCC, 2007) forecasts that developing countries will continue to be affected by extreme weather variability such as temperature, severe water shortage, and floodinducing rainfall events during the coming decades. Weather variability and sea-level rise are the most pressing predicted consequences of climate change with a $0.6{ }^{\circ} \mathrm{C}$ global temperature change, $2 \%$ to $3 \%$ precipitation increase of the tropical latitudes and 3\% precipitation decrease in subtropical areas within the $20^{\text {th }}$ century. Scenarios predict global temperature could increase between $1.4^{\circ} \mathrm{C}$ and $5.8^{\circ} \mathrm{C}$ by the end of the 21 st century (IPCC, 2001). 


\section{Perceived impacts of climate change and variability}

Results from the experimental sampling (Fig. 5) indicate that majority of the rice farmers experienced climate change related problems on their rice farms, either often $(27.8 \%)$ or moderately $(28.8 \%)$. About $35.9 \%$ of the farmers indicated that climate change induced problems on rice production were irregular with variations. Very few farmers $(2.2 \%)$ indicated that climate change effects were very often and consistent on their farms.

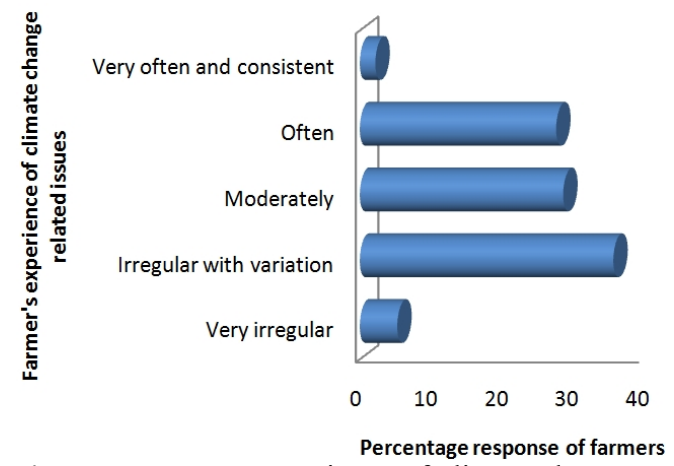

Figure 5. Farmers experience of climate change and related issues in south eastern Nigeria

Table 1 shows climate-related problems affecting rice production in south eastern Nigeria. Responding to the questionnaire (requiring answers like no effect (1); little effect (2), no idea (3), medium effect (4) great effect (5)), rice farmers indicated variation in patterns of adverse effects of climate change on rice production. The highest severe climate change effects were experienced under severe hot temperature $(\bar{X}=4.3)$, late onset of rains $(\bar{X}=3.9)$ and variability in weather condition $(\bar{X}=3.8)$. Acid rain had a low coefficient of mean deviation $(\bar{X}=2.3)$ probably because its effect on rice production is difficult to estimate quantitatively in the farm by smallholder rice farmers.
Table 1. Climate-related problems affecting rice production in south eastern Nigeria

\begin{tabular}{|c|c|c|}
\hline Climate related problems & $\begin{array}{c}\text { Mean } \\
\text { (Max } \\
=5 \text { ) }\end{array}$ & $\begin{array}{l}\text { Std. De- } \\
\text { viation }\end{array}$ \\
\hline Climate variability & 3.8 & 1.0 \\
\hline $\begin{array}{l}\text { Absence of for- } \\
\text { est/deforestation }\end{array}$ & & \\
\hline $\begin{array}{l}\text { est/detorestation } \\
\text { Low rainfall intensity }\end{array}$ & $\begin{array}{l}3.3 \\
3.7\end{array}$ & $\begin{array}{l}1.1 \\
0.9\end{array}$ \\
\hline Acid rain & 2.3 & 1.4 \\
\hline Biodiversity decline & 2.9 & 1.1 \\
\hline Increased water stress & 3.4 & 1.2 \\
\hline $\begin{array}{l}\text { Decrease in length of rice } \\
\text { production }\end{array}$ & 3.3 & 1.1 \\
\hline $\begin{array}{l}\text { Decrease in yield of rain-fed } \\
\text { paddy }\end{array}$ & 3.6 & 1.1 \\
\hline $\begin{array}{l}\text { Reduction in resilience of } \\
\text { agro-ecosystem }\end{array}$ & & \\
\hline by drought & 3.5 & 1.0 \\
\hline Unfriendly flooding & 3.3 & 1.4 \\
\hline Land degradation & 3.5 & 1.3 \\
\hline Loss of arable soil surface & 3.3 & 1.1 \\
\hline Unpredictable loss of water & 3.6 & 1.1 \\
\hline Severe hot temperature & 4.3 & 2.8 \\
\hline Late onset of rains & 3.9 & 1.1 \\
\hline Erosion problem & 3.5 & 1.2 \\
\hline Distortion of rice growth & 3.5 & 1.1 \\
\hline Inadequate tillering & 3.3 & 1.1 \\
\hline $\begin{array}{l}\text { Destruction of paddy fields } \\
\text { by rain }\end{array}$ & 3.4 & 1.2 \\
\hline $\begin{array}{l}\text { Sludge in paddy field due to } \\
\text { heavy wind }\end{array}$ & 3.1 & 1.2 \\
\hline $\begin{array}{l}\text { Abnormal changes in proc- } \\
\text { essed rice }\end{array}$ & 2.8 & 1.3 \\
\hline Sour taste of processed rice & 2.5 & 1.4 \\
\hline $\begin{array}{l}\text { Reduced market of proc- } \\
\text { essed rice }\end{array}$ & 2.9 & 1.4 \\
\hline
\end{tabular}

Source: Field Survey (2011)

There are diverse and mixed views about the indicators of climate change across and within communities in Africa, despite the evidence of a general awareness (Ejembi and Alfa, 2012). In Wenchi, Ghana, farmers listed the following observed changes: Reduction in soil fertility levels, reduction in yields of major staples such as yam and maize disappearance of cocoa as a major cash crop, disappearance of the forest and wildlife, hanges in rainfall 
pattern, proliferation of disease and insect pests proliferation of obnoxious weeds, eg. spear grass. Farmers' own responses to these changes included planting different (early maturing) crops, planting earlier and using more agro-chemicals (Paul et al., 2008).

Empirical results (Ajetomobi et al., 2010) show that climate change is significant to rice agriculture in Nigeria. They established that net revenue per hectare was sensitive to marginal change in climate variables (temperature and precipitation). Sushant (2013) reported that production of rice will be undermined as temperature increases in rice-growing areas with continued climate change. High temperatures decrease rice yield in tropical climate areas (FAO, 2002). Evidence from research also indicates that the net impact of projected temperature increases is to slow the growth of rice. Daily minimum temperature increases, or hotter nights leads to a drop in rice yields (Peng et al., 2004).

\section{Perceived adaptation strategies and con- straints}

In this study strategies employed by rice farmers in south eastern Nigeria in adapting to climate change include: mulching for water conservation especially during nursery preparation, preparation of nursery prior to planting, use of zero tillage, proper site selection, use of fertilizer and agrochemicals, early planting and construction of bonds and drainage to conserve water. The percentage usage of these strategies (technologies) were however low, with only early planting and use of fertilizers recording $38.6 \%$ and $30.4 \%$, respectively (Fig. 6). The rice farmers perceived most of the adaptation strategies as significant in overcoming the effect of climate change in rice production.

Prantilla and Laureto (2013) cited a study by John J. Carroll Institute on Church and Social Issues and reported that rice farmers from Isabela and Iloilo Philippines used the following technologies to cope with climate change effects in their farms: water pump and shallow tube for irrigation, change rice varieties, adjust planting spacing, perform synchronous planting, plant multi-purpose tree species, change planting calendar, practice contour and organic farming, borrow from traders and neighbours, engage in other agricultural production, seek off-farm jobs, and sell assets. Similarly rice farmers in Camarines Philippines have resorted to the use of highyielding and/or early maturing varieties, changing planting dates, diversifying crops, and taking non-farm jobs to cope with the effects of rainfall variability and extremes (Cuesta and Ranola, 2009).

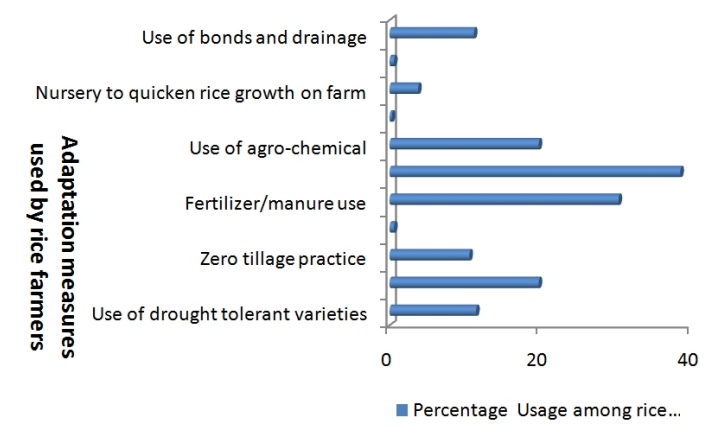

Figure 6. Adaptation measures used by rice farmers to overcome climate change effects in rice production in south eastern Nigeria

Smallholder rice farmers' perception of constraints to adaptation to climate change is shown in Table 2. The major severe constraints based on high mean deviation score include: no subsidies on necessary farm inputs and lack of credit facilities 
$(\bar{X}=4.3)$, lack of climate change information $(\bar{X}=4.2)$, lack of access to improved rice varieties, late supply of inputs, fertilizers and agrochemicals and limited knowledge of adaptation measures available $(\bar{X}=$ 4.4), irregularities of extension services and poor government policy on climate change $(\bar{X}=4.0)$. The least constraining factor is socio-economic and cultural issues $(\bar{X}=$ $3.0)$.

Table 2. Constraints to adaptation and mitigation to climate change in south eastern Nigeria

\begin{tabular}{lcc}
\hline Constraint Issues & Mean & $\begin{array}{c}\text { Std. De- } \\
\text { viation }\end{array}$ \\
\hline $\begin{array}{l}\text { Lack of information } \\
\text { Ineffectiveness of indigenous }\end{array}$ & 4.2 & 1.0 \\
$\quad$ strategies & 3.7 & 1.1 \\
$\begin{array}{l}\text { Irregularity of extension services } \\
\text { No subsidies on necessary farm }\end{array}$ & 4.0 & 1.0 \\
$\quad$ inputs & 4.3 & 0.8 \\
$\begin{array}{l}\text { Lack of credit facilities } \\
\text { Lack of access to improved rice }\end{array}$ & 4.3 & 0.8 \\
$\quad$ varieties & 4.1 & 1.0 \\
$\begin{array}{l}\text { Late supply of inputs, fertilizers } \\
\quad \text { and other agro-chemicals }\end{array}$ & 4.1 & 0.9 \\
$\begin{array}{l}\text { Absence of water management } \\
\quad \text { techniques }\end{array}$ & 3.8 & 1.2 \\
$\begin{array}{l}\text { Inability of farmers to access } \\
\quad \begin{array}{l}\text { available information on cli- } \\
\text { mate change }\end{array}\end{array}$ & 3.9 & 1.1 \\
$\begin{array}{l}\text { Poor land management techniques } \\
\text { Incomprehensive information on }\end{array}$ & 3.8 & 1.1 \\
$\quad$ climate change among farmers & 3.8 & 1.2 \\
$\begin{array}{l}\text { Socio-economic and cultural } \\
\quad \text { issues }\end{array}$ & 3.0 & 1.2 \\
$\begin{array}{l}\text { Traditional values among rice } \\
\quad \text { farmers }\end{array}$ & 3.1 & 1.3 \\
$\begin{array}{l}\text { Poor government policy on cli- } \\
\quad \text { mate change }\end{array}$ & 4.0 & 1.0 \\
$\begin{array}{l}\text { Low institutional support } \\
\text { Limited knowledge on adaptation } \\
\quad \text { measures. }\end{array}$ & 3.9 & 1.0 \\
\hline $\begin{array}{l}\text { Source Field Survey (2011) } \\
\text { (n) }\end{array}$ & 4.1 & 1.0 \\
\hline
\end{tabular}

Source: Field Survey (2011)

The present result confirms the use of inorganic fertilizers, use of improved rice varieties, cultivation of early maturing va- rieties, and proper preservation of rice seeds as important adaptation measures. It corroborates the results of Ajetomobi et al. (2010) who identified improved and early maturing varieties as good adaptation measures to overcome the effects of climate change on rice production in Nigeria. While analyzing farmers' perceptions of climate change, governance and adaptation constraints in the Niger Delta region of Nigeria, Nzeadibe et al. (2011) share similar opinion and confirmed the importance of these factors. They pointed out that the factors responsible for hindering adaptation are inadequate information, limited awareness and knowledge about adaptation methods, and poor government attention to the phenomenon of climate change. Among the local people of Norway, Tiwari et al. (2010) observed that poverty and lack of any government formulated policies and programs have undermined the adaptation strategies in this region.

On the other hand only socioeconomic and cultural issues were regarded by the farmers to be of no serious constraint to adaptation and mitigation to climate change in rice production. This meant that farmers did not see anything wrong in their norms and value orientation systems. This underscores the need for more extension services by the Agriculture Development Programs (ADP) to emphasise proper understanding of the socio-economic and cultural issues of the farmers as preconditions for efficient extension service delivery, including climate change and rice production.

\section{Conclusion}

Changes in climate were well perceived by rice farmers in the study communities. They reported specific knowledge of climate change in terms of changes in rainfall 
regime, intense sunshine, high temperature, frequent pest and diseases outbreak/infestation and reduced yield in their rice farms. High temperature was indicted for causing high heat, reduction in germination and drying of seedlings established in the nursery, while humidity was low, sometimes slowing seed germination.

The adopted strategies by farmers included among others, use of fertililzer and agrochemicals, early planting and construction of bonds cum drainage to conserve water. The percentage usage of these strategies (technologies) were however low. Urgent measures are recommended to be undertaken to improve the resilience of smallholder farmers in rural communities. This will enable them better adapt to climate change. Conscious effort is required to increase the awareness of smallholder farmers and policy makers on climate change. There is need to document climate risks, identify specific problems in relation to rice production, document traditional adaptation measures where available within the study area. The identified constraints constitute areas for intervention in mitigation to effects of climate change on rice production.

\section{Acknowledgements}

This study was financed by African Technology Policy Studies Network (ATPS) grant on Smallholder rice farmers in south eastern Nigeria: constraints, impact, mitigation and adaptation to climate change (ATPS-CSP/0501/10-01)

\section{References}

Adebayo, A.A., J.I. Onu, E.F. Adebayo and S.O. Anyanwu 2012. Farmers' awareness, vulnerability and adaptation to climate change in Adamawa State, Nigeria. British Journal of Arts and Social Sciences 9(2): 104-115.
Agricultural Transformation Agenda (ATA) 2012. Rice Value Chain Document. Federal Ministry of Agriculture and Rural Development, Abuja, Nigeria. pp. 16.

Ajetomobi, J., A. Ajiboye and H. Rashid 2010. Impacts of climate change on rice agriculture in $\mathrm{Ni}$ geria. In The Joint $3^{\text {rd }}$ African Association of Agricultural Economists (AAAE) and $48^{\text {th }}$ Agricultural Economists Association of South Africa (AEASA) Conference, Cape Town, South Africa, September. pp. 19-23.

Akinbobola, T., S.A. Adedokun and P.I. Nwosa 2015. The impact of climate change on composition of agricultural output in Nigeria. American Journal of Environmental Protection 3(2): 44-47.

Benedicta, F., L. Paul, A. Vlek and M. Manschadi 2010. Farmers' perceptions and adaptation to climate change: A case study in Sekyedumase District of Ashanti Region, Ghana. World Food System - A contribution from Europe Tropentag, Zurich.

http://www.tropentag.de/2010/abstracts/full/203.p df. Retrieved 23/11/15

Climate Change Information Resource (CCIR) 2005. What causes global climate change? Climate Change on Agricultural Resources. Norton New York.

Cuesta, M.A. and R. F. Ranola Jr. 2009. Adaptive capacity of rice farmers to rainfall variability and extremes in the Province of Camarines Sur, Philippines. Philippine Agricultural Scientist 92(4): 419- 430.

Deressa, T.T., R.M. Hassan and C. Ringler 2011. Perception of and adaptation to climate change by farmers in the Nile basin of Ethiopia. Journal of Agricultural Science 149: 23-31. doi.org/10.1017/S0021859610000687

Ejembi, E.P. and G.B. Alfa 2012. Perceptions of climate change in Africa: Regional Agricultural Perspectives. Research on Humanities and Social Sciences 2(5): 1-9.

Enete, A.A., I.I. Madu, J.C. Mojekwu, A.N. Onyekuru, E.A. Onwubuya and F. Eze 2011. Indigenous agricultural adaptation to climate change: Study of Imo and Enugu States in Southeast Nigeria. ATPSN Working Paper Series No.53.Retrievedfrom http://www.atpsnet.org/Files/wps53.pdf. Accessed 17/10/2015.

FAO 2002. World Agriculture: Toward 2015/2030 SummaryReport ftp://ftp.fao.org/docrep/fao/004/ y3557e/y3557e00.pdf. Retrieved 15/11/2015 
Intergovernmental Panel on Climate Change (IPCC) 2001. Impacts, adaptation, and vulnerability: contribution of working group II to the third assessment report of the intergovernmental panel on climate change. Cambridge University Press. Cambridge, UK.

Intergovernmental Panel on Climate Change (IPCC) 2007. Impacts, adaptation and vulnerability: an assessment report of the intergovernmental panel on climate change. Cambridge University Press, Cambridge, UK

Jones, P.G. and P.K Thornton 2003. The potential impacts of climate change on maize production in Africa and Latin America in 2055. Global Environmental Change 13: 51-59.

Komba, C. and E. Muchapondwa 2015. Adaptation to climate change by smallholder farmers in Tanzania. Environment for Development, Discussion Paper Series June 15-12: 1-41.

Manneh, B., P. Kiepe, M. Sie, M. Ndjiondjop, N.K. Drame, K. Traore, J. Rodenburg, E.A. Somado, L. Narteh, O. Youm, A. Diagne and K. Futakuchi 2007. Exploiting partnerships in research and development to help African rice farmers cope with climate variability. SAT eJournal|ejournal.icrisat.org 4(1): 1-24.

Nzeadibe, T.C., N.A. Chukwuone, C.L. Egbulen and A.C. Agu 2011. Farmers' perception of climate change governance and adaptation constraints in Niger Delta region of Nigeria. Published by the African Technology Policy Studies Network. ISBN: 978-9966-030-02-3.

Okonya, J.S., K. Syndikus and J. Kroschel 2013. Farmers' perception of and coping strategies to climate change: Evidence from six Agroecological zones of Uganda. Journal of Agricultural Science 5(8): 252-263

Oluwatusin, F.M. 2014. The perception of and adaptation to climate change among Cocoa farm households in Ondo State, Nigeria. Academic Journal of Interdisciplinary Studies 3(1): 147156. doi 10.5901/ajis.2014.v3n1p147

Paul, M., C. Regis, M. Florence, A. Samuel, B. Freddy, M. Ricardo, M. Andrew and G. Ken
2008. Farmers' perceptions lead to experimentation and learning. Agricultures network. LEISA Magazine 24: 4

Peng, S. Huang, J. Sheehy, J.E., Laza, R.C., Visperas, R.M. Zhong, X. Centeno and G.S. Khush 2004. Rice yields decline with higher night temperature from global warming. PNAS 101(27): 9971-9975. http://www.pnas.org/content/101/27/9971.full.pdf . Retrieved: 29/3/15

Prantilla, J.N.D. and A.S. Laureto 2013. Adaptation to climate change of lowland rice farmers in Bukidnon, Philippines: A micro-level analysis. In Philippines Agricultural Economics and Development Association (PAEDA) 2013 BiennialConvention. https://paedacon.wordpress .com/2013/10/14/adaptation-to-climate-changeof-lowland-rice-farmers-in-bukidnon-philippinesa-micro-level-analysis/Accessed 23/11/15

Sushant 2013. Impact of climate change in Eastern Madhya Pradesh, India. Tropical Conservation Science, Special Issue 6(3): 338-364. www.tropicalconservationscience.org Retrieved: 29/3/15

Tiwari, K.R., K.D. Awasthi, M.K. Balla and B.K. Sitaula 2010. Local people's perception on climate change, its impact and adaptation practices in Himalaya to Terai regions of Nepal. $17 \mathrm{p}$ http://www.forestrynepal.org/images/publications /Tiwari_Climate_Change_2010.pdf. Accessed 20/11/2015

Uddin, M.N., W. Bokelmann and J.S. Entsminger 2014. Factors affecting farmers' adaptation strategies to environmental degradation and climate change effects: A farm level study in Bangladesh. Climate 2: 223-241. doi 10.3390/cli2040223

Uzor, N., P.C. Umunakwe, A.O. Ani and F.N. Nnadi 2015. Perceived impacts of cimate change among rural farmers in Imo State Nigeria. African Journal of Agric Science 10(14): 1756-1754.

Zoellick, R.B. 2009. A climate smart future. The Nation Newspapers. Vintage Press Limited, Lagos, Nigeria. 18 p. 